\title{
Relationship Between Family Support and Drug Compliance in Pulmonary Tuberculosis Patients
}

\section{Tri Mochartini"}

Department of Nursing, Sekolah Tinggi IImu Kesehatan Abdi Nusantara, Indonesia

\section{ORCID}

Tri Mochartini: https://orcid.org/0000-0002-4310-3670

Corresponding Author: Tri Mochartini; email:

tri_mochartini@yahoo.com

Published: 7 February 2022

Publishing services provided by Knowledge E

(c) Tri Mochartini. This article is distributed under the terms of the Creative Commons

Attribution License, which permits unrestricted use and redistribution provided that the original author and source are credited.

Selection and Peer-review unde the responsibility of the IVCN Conference Committee.

\begin{abstract}
Tuberculosis (TB) is a disease caused by infection with Mycobacterium tuberculosis. Based on data from the World Health Organization, in 2016 there were roughly 10.4 million TB cases globally (8.8 million-12 million), which is equivalent to 120 cases per 100,000 population. The five countries with the highest incidence of cases are India, Indonesia, China, the Philippines, and Pakistan. The Health Profile of the Ministry of Health of the Republic of Indonesia in 2016 said that the highest number of TB cases in Indonesia was in the province of West Java: 52,328 cases. It is thought that family support can improve the success of one's treatment by helping remind the patient to stay diligent in taking their drugs. This study aimed to determine the relationship between family support and medication adherence in pulmonary TB patients at Pademangan General Hospital in 2020. Purposive sampling was used. The results showed that there was a significant relationship between family support and treatment compliance in these pulmonary TB patients $(p<0.001)$.
\end{abstract}

Keywords: family support, medication compliance, tuberculosis

\section{Introduction}

Tuberculosis (TBC) is an easily contagious disease which in recent years has shown an increase in the number of new cases and deaths caused by TB disease. TB is a disease caused by infection with Mycobacterium tuberculosis [1]. Based on data from the World Health Organization [2] there were 10.4 million TB incident cases (8.8 million-12 million) which is equivalent to 120 cases per 100,000 population. The five countries with the highest incidence of cases are India, Indonesia, China, the Philippines, and Pakistan. Most of the estimated TB incidence in 2016 occurred in the Southeast Asia Region (45\%) where Indonesia is one of them and $25 \%$ occurred in the African region. The world health agency defines high-burden countries (HBC) for TB based on 3 indicators, namely TB, TB/HIV, and MDR-TBC. There are 48 countries included in the list. One country can be included in one of the lists, or both, or even in all three. Indonesia, along with 13 other countries, are included in the HBC list for the 3 indicators. This means that 
Based on the Data and Information Information Center of the Ministry of Health of the Republic of Indonesia, the highest number of TB cases in Indonesia was in the province of West Java with 52,328 cases, of which 29,429 were male and 22,899 were female. Then the second rank is Central Java with 28,842 cases. Followed by DKI Jakarta with 24,775 cases and North Sumatra with 17,798 cases, while in Gorontalo with 1,151 cases. Based on these data, DKI Jakarta ranks third with the most TB cases in Indonesia [1]. As an effort to control the spread of pulmonary TB disease in DKI Jakarta, the government emphasizes the Directly Observed Treatment Shortcourse (DOTS) program strategy. The program provides all anti-TB drugs on a regular, comprehensive and timely basis, which is an important point proclaimed by the Government. If left untreated, TB disease causes long-term illness, disability and death. Approximately $50 \%$ of patients with untreated pulmonary tuberculosis will die within 5 years, the majority of these $50 \%$ will die within 18 months. In addition, people with TB disease who are not treated properly can transmit TB bacteria to their families, including children, they also cannot get along freely. One of the strategies of DOTS is the implementation of short-term OAT guidelines with supervision from the Drug Swallowing Supervisor (PMO) as an effort to take medication compliance. [1]Family support is the closest and inseparable part of the sufferer. Patients will feel happy and at ease when they receive attention and support from their families, because with this support it will increase their confidence to deal with or manage their illness better, and the patient is willing to follow the suggestions given by the family to support the management of the disease [3].

According to $[4,5]$, describe 4 types of family support, namely: First, emotional support: namely communicating love, care, trust in family members (tuberculosis patients). Second, instrumental support: helping people directly include giving money and household chores. This instrumental support refers to the provision of goods, or services that can be used to solve practical problems. Third support Information: aspects in this support is to provide advice, suggestions, suggestions, instructions and providing information. The family functions as a collector and disseminator of information about the world. Fourth, reward support: this type of support occurs through the expression of positive appreciation for the individual, encouragement or agreement with other individuals' ideas or feelings.

Based on a preliminary study conducted by researchers in December 2019 regarding pulmonary TB disease at the DOTS Poly RSUD Pademangan, it was reported that since the last 3 months the percentage of pulmonary TB cases has increased compared to other disease cases, September 2019 as many as 87 people, October 2019 as many as 89 people and November 2019 as many as 91 people. Therefore this study 
aimed to explore relationship of family support and medication adherence in pulmonary Tuberculosis patients.

\section{Methods}

\subsection{Design}

This study used analytic survey with a Cross Sectional approach at DOTS outpatient department, Pademangan General Hospital, Indonesia.

\subsection{Sample}

The sample in this study were some who had tuberculosis and growth and development in toddlers as many as 71 patients with pulmonary TB at the DOTS Poly, Pademangan Regional General Hospital.

\subsection{Procedure}

This research was conducted at the Pademangan Regional General Hospital, North Jakarta from January to March 2020 on all patients who visited the DOTS TB Polyclinic, totaling 71 pulmonary TB patients. The data required consists of medication adherence, family support, emotional support, instrumental support, and informational support.

\subsection{Questionnaire for Data Collection}

\subsection{Data Analysis}

Data processing used computerized SPSS 25.0. The analysis used is Univariate and Bivariate (Chi-square) using the limit of significance Alpha $=<0.05$

\section{Results}

\section{Discussion}


TABLE 1: Distribution of Frequency of Medication Adherence among Pulmonary TB Patients at the DOTS outpatient department, Pademangan General Hospital, January 2020

\begin{tabular}{l|l|l} 
Medication Compliance & Frequency & Percentage \\
\hline Obey & 28 & $39.4 \%$ \\
\hline Not obey & 43 & $60.6 \%$ \\
\hline Total & 71 & $100.0 \%$
\end{tabular}

TABLE 2: Frequency Distribution of Family Support for Pulmonary TB Patients at DOTS outpatient department, Pademangan General Hospital, January 2020

\begin{tabular}{l|l|l|}
\hline Family Support & Frequency & Percentage \\
\hline Good & 25 & $35.2 \%$ \\
\hline Less & 46 & $64.8 \%$ \\
\hline Total & 71 & $100.0 \%$
\end{tabular}

\subsection{Frequency Distribution of Medication Adherence in Pulmonary TB Patients at DOTS outpatient department, Pademangan General Hospital, January 2020}

The results of this study was in accordance with the theory of patient compliance in the intensive phase of tuberculosis treatment, namely the patient receives medication every day without stopping and is directly supervised to prevent immunity to all Anti Tuberculosis Drugs (OAT), especially refamicin, patients take medication for at least two months [1]. Researchers assumed that respondents lack knowledge about the importance of taking medication regularly. This was supported by the characteristics of respondents who are highly educated (college/academic), totaling 3 respondents who were all obedient in treating pulmonary TB.

TABLE 3: Distribution of the Frequency of Emotional Support and Awards for Pulmonary TB Patients at DOTS outpatient department, Pademangan General Hospital, January 2020

\begin{tabular}{l|l|l} 
Emotional Support & Frequency & Percentage \\
\hline Good & 33 & $46.5 \%$ \\
\hline Less & 38 & $53.5 \%$ \\
\hline Total & 71 & $100.0 \%$
\end{tabular}


TABLE 4: Frequency Distribution of Instrumental Support in Pulmonary TB Patients at DOTS outpatient department, Pademangan General Hospital, January 2020

\begin{tabular}{l|l|l} 
Instrumental Support & Frequency & Percentage \\
\hline Good & 31 & $43.7 \%$ \\
Less & 40 & $56.3 \%$ \\
Total & 71 & $100.0 \%$
\end{tabular}

TABLE 5: Frequency Distribution of Information Support for Pulmonary TB Patients at DOTS outpatient department, Pademangan General Hospital, January 2020

\begin{tabular}{l|l|l}
\hline Information Support & Frequency & Percentage \\
\hline Good & 31 & $43.7 \%$ \\
\hline Less & 40 & $56.3 \%$ \\
\hline Total & 71 & $100.0 \%$
\end{tabular}

\subsection{Frequency Distribution of Family Support Relationships on Compliance with Taking Drugs in Pulmonary TB Patients at DOTS outpatient department, Pademangan General Hospital, January 2020}

Based on the results of the Chi-quare statistical test, the $P$ Value is 0.000 ( $P$ Value $<0.05$ ), which means that $\mathrm{HO}$ is rejected. Ha is accepted, which means that there is a relationship between family support and medication adherence in pulmonary TB patients at Pademangan Hospital in January 2020.

The results of the study with the same title as the researcher conducted by[6], in line with the results of the frequency distribution of family support relationships on medication adherence in pulmonary TB patients at the Ranotana Weru Health Center, Manado from 66 respondents with good support, 17 respondents ( $25.8 \%$ ) and less family support as many as 49 respondents (74.2\%). The test results show that family support with medication adherence is related $(P=0.000)$ and the research conducted by is also in line with [7] the results conducted by researchers, namely the results of family support at the Umbulharjo I health center being mostly good (65.4\%) and most patients adhere to medication (77.3\%), the Chi-quare test results obtained a value $(0.008)$ and contingency coefficient results $(r=0.506)$, so there is a significant relationship between family support and medication adherence in pulmonary TB patients. At the Umbulharjo I Health Center, Yogyakarta, the relationship was moderate.

The results of the study are in accordance with [4] theory that family support is the closest and inseparable part of the sufferer. Patients will feel happy and at ease when they receive attention and support from their families, because with this support it will increase their confidence to deal with or manage their illness better, and the patient 
is willing to follow the suggestions given by the family to support the management of the disease. Researchers found that there was some lack of family support and even overall so that it affected medication adherence.

Researchers assume this is because most respondents have jobs that require respondents to do more activities outside the home so that the proportion of meetings at home is short and limited, causing communication between families to be less than optimal, if communication in the family is effective, the family will easily recognize emotional needs, appreciation, instrumental and patient information and this can also be related to the researcher that most of the respondents did not know who the patient was infected from or the respondent did not know. The family also gives less freedom to the patient to take the freedom to make decisions related to their needs and is more dominantly taken over by the family.

\subsection{Emotional support and appreciation for medication adherence in pulmonary TB patients}

Based on the results of the Chi-quare statistical test, the $P$ Value is 0.000 ( $P$ Value $<0.05$ ), which means $\mathrm{HO}$ is rejected, $\mathrm{Ha}$ is accepted, which means that there is a relationship between emotional support and appreciation for medication adherence in pulmonary TB patients in patients at Pademangan Hospital in January 2020.

The results of the research which are not the same in title but have the same variables as the researchers conducted by [8] are in line with the pins with the results that 18 respondents (27\%) good emotional support while 48 respondents $(73 \%)$ lacked emotional support with the acquisition of a bivariate Pvalue analysis. $=0.01$ with $P<0.05$, $\mathrm{Ha}$ accepted means that there is a relationship between emotional support and appreciation with medication adherence in patients at the RSJ.Prof.DR.Muhammad Ildream Polyclinic Medan.

The results of the study are in accordance with the theory of $[4,5]$. Emotional support is communicating love, care, and trust in family members (TB patients). Family as a safe and peaceful place for rest and recovery and helps mastery of emotions and appreciation support where this type of support occurs through positive expressions of appreciation for the individual, encouragement to go forward or agreement with the ideas or feelings of other individuals.

Researchers assume that the lack of emotional support is caused by communication factors in the family that are still not optimal. If communication within the family is still lacking or ineffective, the family cannot recognize the emotional needs needed 
by pulmonary TB patients and this lack of appreciation can be influenced by the lack of patient autonomy in making decisions regarding their treatment because decision making is still dominated by the family.

\subsection{Instrumental Support for Drug Compliance in Pulmonary TB Patients}

Based on the results of the Chi-quare statistical test, the $P$ Value is 0.000 ( $P$ Value $<0.05$ ), which means that $\mathrm{HO}$ is rejected. $\mathrm{Ha}$ is accepted, which means that there is a relationship between instrumental support and medication adherence in pulmonary TB patients in patients at the Pademangan Hospital in January 2020.

The results of the research which are not the same in title but the variables are the same as the researchers conducted by [8] are in line with the pins with the results that Instrumental support is good 8 respondents (11\%) while Instrumental is less 58 respondents (89\%) with the acquisition of bivariate Pvalue analysis $=0.01$ with $\mathrm{P}<0.05, \mathrm{Ha}$ is accepted, which means that there is a relationship between instrumental support and medication adherence in patients at the Polyclinic of RSJ.Prof.DR.Muhammad Ildream Medan.

The results of the study are in accordance with the theory put forward by Taylor (1995), that instrumental support is needed for tuberculosis patients, especially patients who are not compliant with pulmonary TB drugs, support can help meet the needs of the patient.

The researcher assumes where the researcher finds influential factors such as factors that are needed by the patient for example not delivering the patient when checking health and income or the family's economic status and the income earned by the family is low, it is difficult for the family to provide the needs needed by the patient for optimal treatment.

\subsection{Information Support for Compliance with Taking Drugs in Pul- monary TB Patients}

Based on the results of the Chi-quare statistical test, the value of $P$ Value is 0.000 ( $P$ Value $<0.05$ ), which means that $\mathrm{HO}$ is rejected. $\mathrm{Ha}$ is accepted. There is a relationship between instrumental support and medication adherence in pulmonary TB patients in patients at the Pademangan Hospital in January 2020. 
The results of the study are not the same as the title but the variables are the same as the researchers conducted by Uswatul Khasanah (2019) such as having good information support $45 \%$ with the acquisition of bivariate analysis Pvalue $=0.011$ with $P$ $<0.05, \mathrm{H} 1$ is accepted there is a relationship between information support and drinking compliance medicine in patients at the Ciracas sub-district health center.

The results of the study are in accordance with [4], that information support where aspects of this support are providing advice, suggestions, instructions, and providing information. Families work as collectors and disseminators of information about the world [3].

The researcher assumes that the family only gets information from health workers and not with the intensity of the family's exposure to sources where the information can be obtained such as: newspapers, TV, magazines, radio and neighbors' experiences. If the family is rarely exposed to the sources of information above, the family only gets some information about the patient's health. The acceptance or acceptance of information received by the family can also be influenced by the level of education where most of the respondents have an elementary school education background.

\section{Funding}

No Funding for this study.

\section{Conflict of Interest}

We declare no conflict of interest.

\section{References}

[1] Ministry of Health of Republic of Indonesia. Tuberculosis. 2018. Available from: https://pusdatin.kemkes.go.id/resources/download/pusdatin/infodatin/infodatintuberkulosis-2018.pdf

[2] World Health Organization. Global tuberculosis report 2016. Geneva: World Health Organization; 2016.

[3] Friedman, F. Textbook of family nursing research, theory and practice. Yogyakarta: EGC; 2018.

[4] Friedman MM. Family nursing: Theory and practice. McGraw-Hill/Appleton \& Lange; 1992. 
[5] Bomar PJ, Hanson SMH, Bell JM, Friedman MM. Family nursing: Research, theory, and practice.

Wright LM, Leahey M. Nurses and families: A guide to family assessment and intervention.

[6] Pitters TS, Kandou GD, Nelwan JE. Family support in relation to medication compliance in pulmonary tuberculosis patients at Ranotana Weru Health Center. KESMAS. 7.

[7] Shaufatus M. Relationship of family support towards compliance with drugs in pulmonary TB patients at puskesmas umbulharjo 1 Yogyakarta. Universitas Aisyiah Yogyakarta. Yogyakarta. 2018. Available from: http://digilib.unisayogya.ac.id/3968/

[8] Ginting SB. The relationship of family support with medicine compliance in schizoprenia patients in the poly clinic of Rsj Prof. Dr. Muhammad Ildrem MedanJurnal IImiah PANNMED (Pharmacist, Analyst, Nurse Midwifery). 2019;14:2631. 